\title{
Mineralogical Characteristics of Garnet in Garnet Mica Schist and Its Tectonic Significance in the Tongbai Section of the Shangdan Fault Zone
}

\author{
Shenglian Ren*, Chuanzhong Song, Jiahao Li \\ School of Resources and Environmental Engineering, Hefei University of Technology, Hefei, China \\ Email: ren lotus@126.com, czsong69@163.com, lijiahaohappy@sina.com
}

Received 29 December 2014; accepted 22 January 2015; published 26 January 2015

Copyright (C) 2015 by authors and Scientific Research Publishing Inc.

This work is licensed under the Creative Commons Attribution International License (CC BY). http://creativecommons.org/licenses/by/4.0/

(c) (i) Open Access

\section{Abstract}

Studies on the metamorphism and deformation conditions of rocks in the suture zone are good ways to discuss the orogenic process and mechanism. The microstructure and ultramicrostructure features of minerals are true embodiment of formation environment of the orogenic belt. Based on the study of microstructure, ultramicrostructure deformation characteristic and compositional zonation of garnets in garnets-mica schists in the Tongbai mountain, east section of the Shangdan fault zone, the results show that the three types of garnets have suffered various states of plastic deformation. The dynamic recrystallization of garnets is due to the subgrain growth and boundary migration. The dislocations are mainly free dislocation and dislocation walls. The free dislocation density $\rho=6.14 \times 10^{8} / \mathrm{cm}^{2}$, and dislocation movement are mainly slips; slip planes are $1 / 2<111>$ $\{110\}$ and $\langle 100\rangle\{001\}$. Garnet microprobe analysis shows that it belongs to almandine, and reflects it has undergone epidote-amphibolite to amphibolite facies metamorphism. Compositional zonation of garnet shows that the rocks had experienced progressive metamorphism. First metamorphic environment was continuous temperature-pressure and in mid-term there were two non-synchronous transient cooling and decompression processes, and it finally underwent decompression and warming process of the thermal relaxation environment. The formation condition of garnet-mica schist is estimated: $\mathrm{T}=562^{\circ} \mathrm{C}-617^{\circ} \mathrm{C}$, and $\mathrm{P}=0.77-1.02 \mathrm{GPa}$. The differential stress is $0.511 \mathrm{GPa}$ and strain rate is $4.97536 \times 10^{-10} \mathrm{~m} / \mathrm{s}$. After systemic analysis, a conclusion is drawn that the plastic deformation mode, deformation mechanism and formation environment of garnets are closely related to the formation and development of the Shangdan fault zone. It truly reflects that the Shangdan fault zone, as the suture zone of Yangtze and north China plate, has been subjected to early medium-grade metamorphism. With the continuous compression after the collision, the left-lateral shearing happened and caused the formation of high density dislocations

\footnotetext{
${ }^{*}$ Corresponding author.
} 
and subgrains of the garnets; finally the plastic deformation happened and the bulging recrystallization formed in the period of heat relaxation had a relative low stress.

\title{
Keywords
}

\author{
The Tongbai Area, The Shangdan Fault Zone, Metamorphism and Deformation, Compositional \\ Zonation of Garnet, Dislocation
}

\section{Introduction}

The Central Orogenic Belt is one of the key areas where the Eastern Paleo-Tethyan ocean closed and consequently the adjacent blocks and terranes collided. The belt comprises Qilian mountain, Kunlun mountain and Songpan mountain in the west which converge to Qinling, Tongbai and Dabie mountains in the east. This belt is attributed to the intracontinental orogeny in the late Cenozoic [1]. Qinling, Tongbai and Dabie mountains of the central orogen are the result of subduction of the Yangtze plate and its collision with the North China plate. The Shangdan fault zone as the suture zone of the two plates is recognized by many geologists [1] [2]. Study of the fault zone is helpful to reveal the mechanism, process and tectonic environment of the deep subduction and the regional metamorphism involved. Metamorphism study and deformation structural analysis of rocks within the suture are the key.

\section{Geology Setting}

The Shangdan fault in the Tongbai area of the suture zone is an important tectonic boundary. To its north and South are respectively the Northern Tongbai and the Southern Tongbai, corresponding to southern Qinling and Northern Qinling in the Qinling Mountains area. Shangdan fault is well exposed only to the north of Tongbai mountain and west of Xingyang due to the subsequent tectonic destruction after it developed. It is about 1 - $3 \mathrm{~km}$ wide and up to $45 \mathrm{~km}$ long in east-west direction. Various ductile deformation structures are observed in the field. Mylonitic foliation generally dips toward south with dip mostly at more than $60^{\circ}$. Lineation plunges to $280^{\circ}-340^{\circ}$ with plunge of $15^{\circ}-30^{\circ}$. A variety of kinematic indicators suggest that Shangdan fault zone in Tongbai is a large sinistral ductile shear zone.

To the south of Shangdan fault zone is Tongbai gneiss uplift belt. To the north are Hongyi River-Luozhuang eclogite belt and Maopo-Hu Jiazhai volcano rock belt. Tongbai gneiss uplift belt is also known as the Tongbai complex. The rock is mainly composed of granitic gneiss, black mafic inclusions and marble lens. Schistosity dips to the southwest. The dip angle is $30^{\circ}-40^{\circ}$. Rocks in Hongyi River-Luozhuang eclogite belt are garnet mica schists, glaucophane schist, amphibolite schists and different components of blastomylonite [3]. Schistosity dips to northeast. Dip angle is in the range of $25^{\circ}-35^{\circ}$. A large amount of veins, lenticular or layered eclogite or garnet amphibolite are exposed in the Hongyi River, Luozhuang temple and goddess temple. They are a few hundred centimeters in size. Its occurrence is consistent with eclogite in Dabie area. Hongyi River-Luozhuang eclogite belt is in contact with the Maopo-Hu Jiazhai volcano rock belt at a normal fault. The rocks in Shangdan fault zone are felsic schist and gneiss, containing a small amount of marble lens and amphibolite interlayers [4]. The samples were collected from the southwest side of Xinyang City (Figure 1). The lithology is garnet mica schist whose composition is consistent with Hongyi River-Luozhuang eclogite outside of the fault zone, and it is interpreted as derived from deformed equivalence to the eclogite [5]. In this study, we present the mineralogical study and the formation environment of garnet, and use them to reveal the tectonic evolution of Shangdan fault zone in Tongbai area.

\section{The Deformation Characteristics of Garnet Mica Schist}

\subsection{Mineral Assemblages of Garnet Mica Schist}

The mineral assemblage of the garnet mica schist is quartz, muscovite, biotite, garnet, epidote and a small amount of feldspar. The garnet mica schist has a porphyroblastic structure and porphyroblasts are garnets. The 


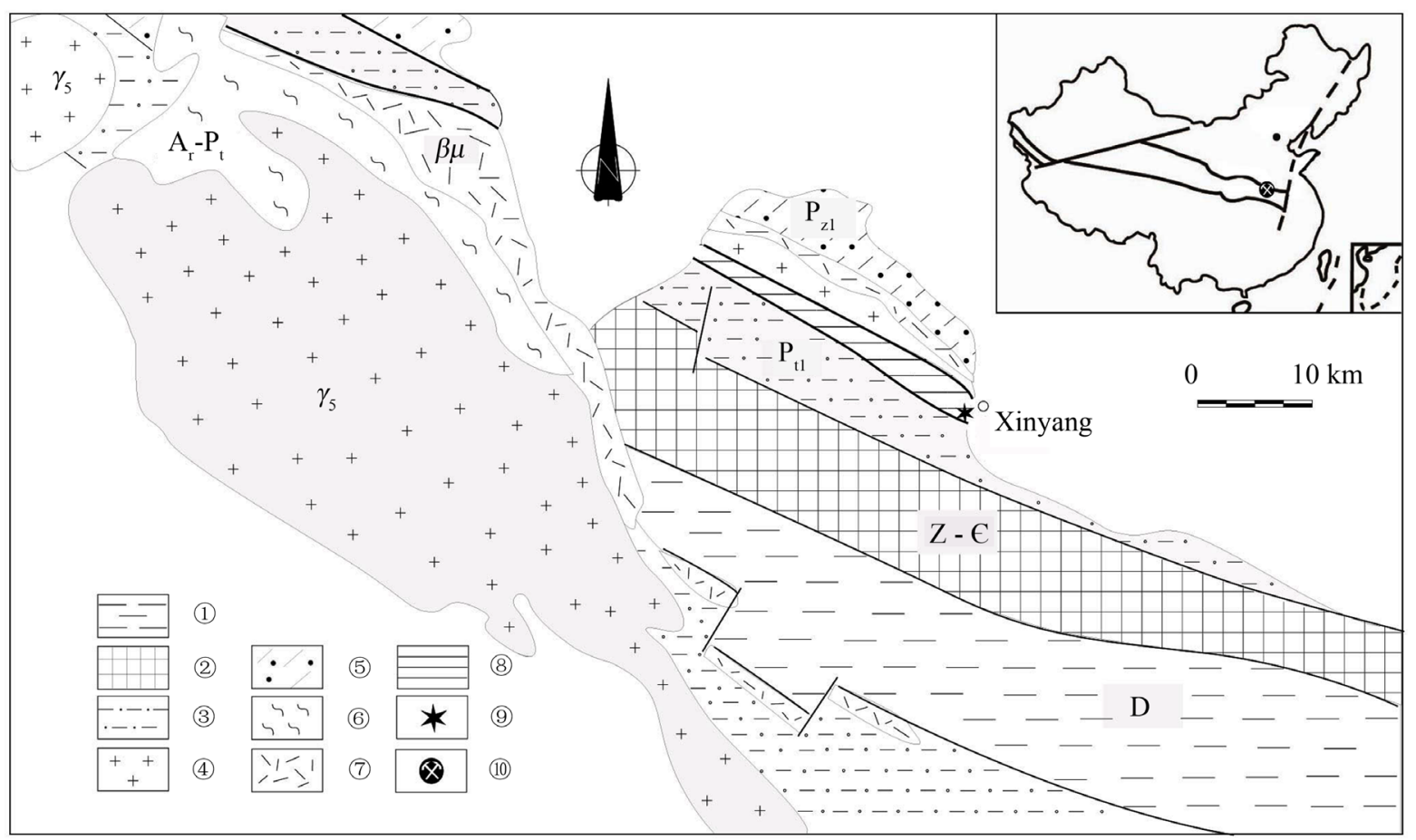

Figure 1. Geological map of work area and sampling location. 1. Devonian metasandstone; 2. Greenschist of Foziling group; 3. Tongbai gneiss uplift belt; 4. Yanshanian volcanic belt of Maopo-Hujiazhai; 5. Basic rock of Erlangping; 6. Granitic gneiss; 7. Indosinian basic rock; 8. Eclogite belt of Hongyihe-Luozhuang; 9. Sample location; 10. Work area.

matrix is quartz, muscovite, biotite, epidote and plagioclase. Matrix has fine crystalloblastic or micro lepidoblastic texture, and schistose structure. Rocks show strong ductile deformation. Quartz occurs as ribbons with sweeping undulose extinction and aspect ratios of more than 10:1 (Figure 2(a)). Static recrystallization is visible in quart ribbons and is interpreted as having formed in later tectonic thermal relaxation. Muscovites occur at both sides of garnet and gather in the garnet pressure shadows. The muscovites are elongated and have a preferred orientation. Biotite and Muscovite coexist and together define the foliation. Small biotites occur in garnet pressure shadows or at the edge of garnet. Epidote show the shape of datestone in the matrix (Figure 2(b)). Some occur in garnet pressure shadows. Matrix possess fine crystalloblastic or micro lepidoblastic texture. In the $\mathrm{XZ}$ surface, the "S-C" structure is obvious.

\subsection{The Deformation Characteristics of Garnets}

According to the mineralogical characteristics of garnet porphyroblasts in the sample, garnet can be divided into three categories. Garnets $\left(\mathrm{Gt}_{1}\right)$ in the first category are rounded or dodecahedral in shape. Inclusions are abundant in the garnets and define concentric rings which are clearly visible under the microscope. Large garnet crystals have 3 - 5 zones separated by the rings (Figure 2(c)). The sizes of the garnets vary between $1-0.5 \mathrm{~mm}$. Garnet porphyroblasts is surrounded by foliations in the matrix, and pressure shadow is visible. These porphyroblasts and the pressure shadows together have monoclinic shape symmetry, and are " $\sigma$ " type mantled clasts. The asymmetry indicates sinistral shearing. The garnets $\left(\mathrm{Gt}_{2}\right)$ in the second category are with helicitic structure. Inclusions of quartz and mica align to define the internal foliation within gargets. The internal foliations form spiral patterns (Figure 2(d)), and these garnets are "snowball" garnets. The foliations can be traced continuously from the internal foliation in the garnets to the external foliations outside of the garnets in the matrix. This characteristic suggests that these garnets grew while it was rotating during the non-coaxial deformation [6]. Garnets $\left(\mathrm{Gt}_{3}\right)$ in the third category are small and subrounded to rounded in shape, similar to the garnets in the first category but with fewer or no rings defined by inclusions.

All garnet clasts developed before the end of deformation, which is suggested by that all garnets are associated with pressure shadows and are wrapped by late foliations. Micro-structure study reveals that garnets in the 

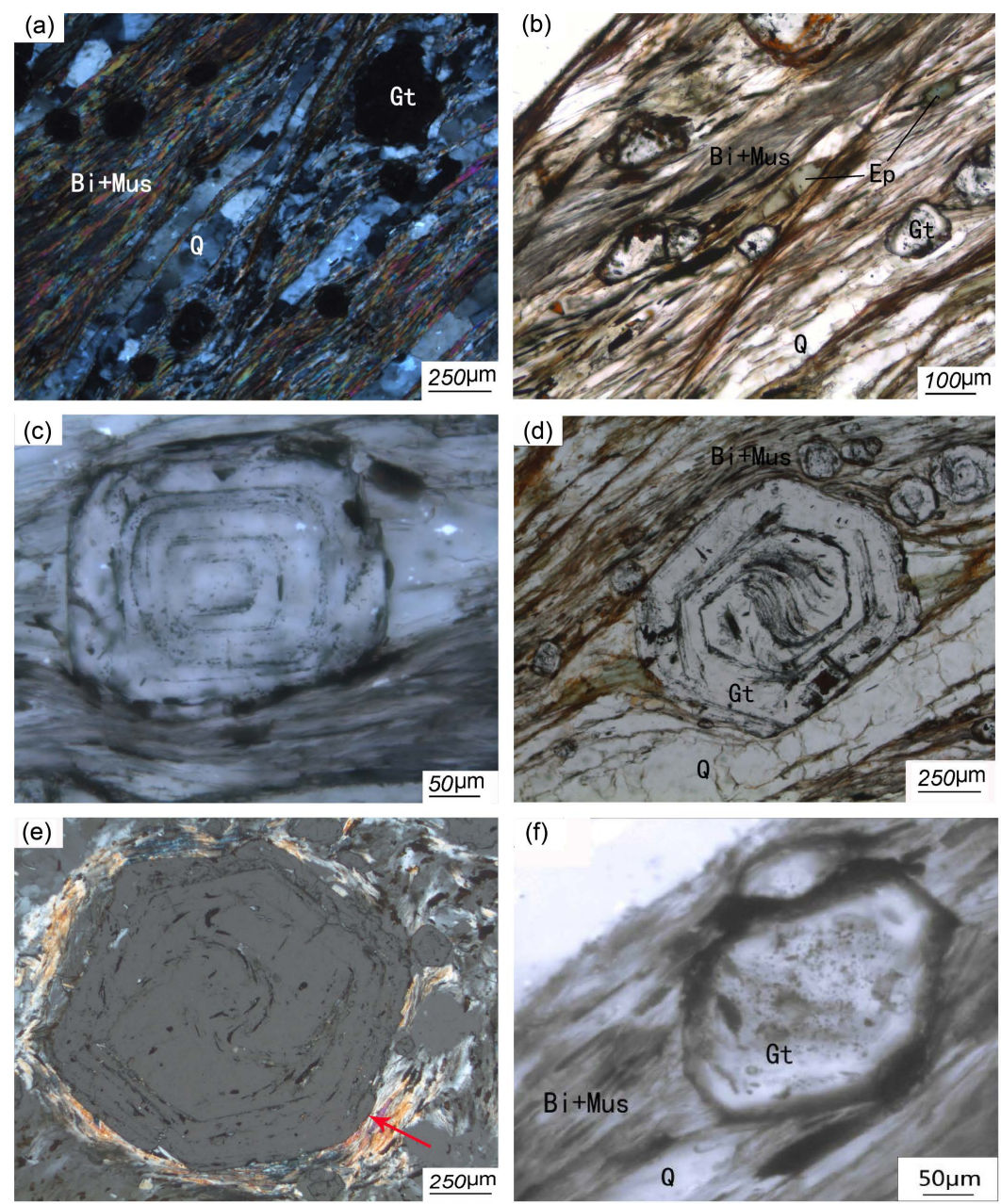

Figure 2. Micrographs of garnet-mica schist. (a) Quartz vein, epidote and garnet $\left(\mathrm{Gt}_{3}\right)$ in the spectrum; (b) Type I garnet $\left(\mathrm{Gt}_{1}\right)$; (c) (d) Type II garnet $\left(\mathrm{Gt}_{2}\right)$; (e) (f) Dynamic recrystallization of garnets and "core-mantle structure".

three different categories grew at different stages of deformation. $\mathrm{Gt}_{2}$ garnets have inner cores with spiralshaped inclusions and outer edges with concentric-ringed inclusions. $\mathrm{Gt}_{1}$ and $\mathrm{Gt}_{3}$ garnets do not have inner core but contain inclusions with patterns similar to those in the outer edge of $\mathrm{Gt}_{1}$ garnets. Dynamic recrystallized garnets occur at the margins of $\mathrm{Gt}_{1}$ and $\mathrm{Gt}_{2}$, and their shapes are similar to $\mathrm{Gt}_{3}$ garnets (Figure 2(e) and Figure 2(f)). The similarities between $\mathrm{Gt}_{1}, \mathrm{Gt}_{3}$, and outer part of $\mathrm{G}_{3}$ garnets suggest that they might grow during the same sage. The inner core of $\mathrm{Gt}_{2}$ grew at an early stage and $\mathrm{Gt}_{1}, \mathrm{Gt}_{3}$, and outer part of $\mathrm{G}_{3}$ garnets grew at a later stage. Garnets of all the samples are syntectonic with the suture zone deformation.

Although garnets in each category have their own characteristics, all garnets are syntectonic garnets. This can be interpreted with decomposition of deformation [7]. Bell noted that inhomogeneity of the geological structure of native or heterogeneity of deformation, resulting in deformation of rock inhomogeneity. In progressive deformation process, rock deformation can be decomposed into progressive sheer deformation component and progressive shortened deformation component, and usually layered silicate minerals like mica minerals occupy sheer deformation domain, as mica class mineral; in shortened deformation domain there is usually granular phenocryst minerals. When it grows it is vulnerable to shear deformation domain on both sides, the neighboring mostly flaky mineral, and such metacrystal typically grow larger. Porphyroblasts is generally not easy to nucleation grow in deformation component parts where the mica mineral gathered, however, under certain conditions when strain rate is very small, growth of phenocrysts is in priority within the deformation zone where mica minerals gathered, because in this band there is not only the material elements required to build the phenocrysts, and also it is at a relatively static environment [8]. Phenocrysts particles in these two growth environments, the for- 
mer is lager and the latter particles smaller and easy to produce "s-shaped" or "snowball-like" structure. Therefore, they are products at different stages in the process of deformation, belonging to the same tectonic origin.

\section{Characteristics of Garnet Composition}

\subsection{Crystal Chemistry of Garnet}

Garnet chemical equation can be written as $\mathrm{A}_{3} \mathrm{~B}_{2}\left[\mathrm{SiO}_{4}\right]_{3}$, where A represents bivalent cation $\mathrm{Ca}^{2+}, \mathrm{Mn}^{2+}, \mathrm{Fe}^{2+}$, $\mathrm{Mg}^{2+}, \mathrm{Na}, \mathrm{K}$, and $\mathrm{Y}$, etc., and $\mathrm{B} \mathrm{Al}{ }^{3+}, \mathrm{Fe}^{3+}, \mathrm{Cr}^{3+}, \mathrm{V}^{3+}, \mathrm{Ti}^{4+}$, and $\mathrm{Zr}^{4+}$, etc. One of the most important crystal chemistry of garnet is their crystal structures are complex. Most garnet is body-centered cubic crystal system with space group of Ia3d. Isolated $\left[\mathrm{SiO}_{4}\right]$ tetrahedra in crystal structure is connected by coordination polyhedron $\left[\mathrm{BO}_{6}\right]$ which is composed of cations of category $\mathrm{B}\left(\mathrm{Al}^{3+}, \mathrm{Fe}^{3+}, \mathrm{Cr}^{3+}\right.$, and $\mathrm{V}^{3+}$ etc.). In the course of the formation of distortion large cubic space, it is occupied by class A cation, forming distortion cubic coordination polyhedron $\left[\mathrm{AlO}_{8}\right]$.

It is well known that temperature and pressure conditions have an impact on cation coordination number of the crystal structure, such as: warming causes cationic coordination number decreases, booster increases the coordination number. Cationic coordination number and composition reflect the forming environment of garnets. Typically, the coordination number of A class cationic of Garnet $\left(\mathrm{Ca}^{2+}, \mathrm{Mn}^{2+}, \mathrm{Fe}^{2+}\right.$, and $\left.\mathrm{Mg}^{2+}\right)$ is 8 , due to the radius of the $\mathrm{Ca}^{2+} 0.112 \mathrm{~nm}$, eight times of coordination is appropriate, without too much pressure. Therefore, the formation of grossular andradite, do not need too much pressure, mostly formed in the contact metamorphic band where pressure is not big, while ionic radius of $\mathrm{Mn}^{2+}(0.096 \mathrm{~nm}), \mathrm{Fe}^{2+}(0.092 \mathrm{~nm}), \mathrm{Mg}^{2+}(0.089 \mathrm{~nm})$ is smaller, and it decrease follow this order. In general they tend to enjoy six times coordination, it needs pressure increased conditions if they enjoy eight times coordination, so spessartine generates in low-level regional metamorphic conditions with pressure slightly high, while almandine generates in intermediate regional metamorphic conditions with higher pressure, and pyrope only generates in conditions of very high pressure, as eclogite, and kimberlite [9]. Therefore, temperature-pressure conditions of the formation of garnet can be estimated by use of content and variety of $\mathrm{Ca}, \mathrm{Mn}, \mathrm{Fe}, \mathrm{Mg}$ components of garnet.

\subsection{The Composition of Garnets in the Garnet Mica Schist and Their Significance}

This section presents electron microprobe analysis results for the three types of garnets (Tables 1-3). The analy-

Table 1. The compositions of garnet for sample 09-2914-1.

\begin{tabular}{|c|c|c|c|c|c|c|c|c|c|c|}
\hline \multirow{2}{*}{$\frac{\text { Composition }}{\mathrm{Na}_{2} \mathrm{O}}$} & \multicolumn{10}{|c|}{ Center edge } \\
\hline & 0.06 & 0.00 & 0.04 & 0.07 & 0.08 & 0.03 & 0.06 & 0.00 & 0.03 & 0.02 \\
\hline $\mathrm{FeO}$ & 28.50 & 28.86 & 29.49 & 30.48 & 30.82 & 31.92 & 32.27 & 31.57 & 32.71 & 33.58 \\
\hline $\mathrm{K}_{2} \mathrm{O}$ & 0.00 & 0.01 & 0.00 & 0.00 & 0.01 & 0.00 & 0.01 & 0.00 & 0.00 & 0.02 \\
\hline $\mathrm{SiO}_{2}$ & 37.07 & 37.23 & 37.03 & 37.07 & 36.23 & 36.92 & 36.91 & 37.17 & 36.83 & 38.07 \\
\hline $\mathrm{MnO}$ & 5.98 & 5.89 & 5.34 & 5.01 & 3.95 & 4.00 & 3.22 & 2.71 & 1.69 & 1.58 \\
\hline $\mathrm{MgO}$ & 1.32 & 1.28 & 1.40 & 1.45 & 1.45 & 1.60 & 1.58 & 1.77 & 2.01 & 2.09 \\
\hline $\mathrm{CaO}$ & 4.78 & 4.75 & 4.52 & 4.14 & 5.14 & 3.62 & 4.11 & 4.56 & 4.46 & 3.91 \\
\hline $\mathrm{Al}_{2} \mathrm{O}_{3}$ & 20.90 & 21.00 & 20.90 & 21.02 & 21.60 & 20.98 & 21.15 & 21.11 & 21.18 & 21.39 \\
\hline Total & 98.61 & 99.10 & 98.73 & 99.26 & 99.40 & 99.08 & 99.37 & 98.90 & 98.94 & 100.64 \\
\hline $\mathrm{Na}$ & 0.02 & 0.00 & 0.01 & 0.02 & 0.03 & 0.01 & 0.02 & 0.00 & 0.01 & 0.01 \\
\hline $\mathrm{Fe}$ & 3.89 & 3.92 & 4.02 & 4.14 & 4.19 & 4.35 & 4.38 & 4.29 & 4.45 & 4.47 \\
\hline $\mathrm{K}$ & 0.00 & 0.00 & 0.00 & 0.00 & 0.00 & 0.00 & 0.00 & 0.00 & 0.00 & 0.00 \\
\hline $\mathrm{Si}$ & 6.05 & 6.05 & 6.04 & 6.02 & 5.89 & 6.01 & 5.99 & 6.03 & 5.98 & 6.06 \\
\hline $\mathrm{Mn}$ & 0.83 & 0.81 & 0.74 & 0.69 & 0.54 & 0.55 & 0.44 & 0.37 & 0.23 & 0.21 \\
\hline $\mathrm{Mg}$ & 0.32 & 0.31 & 0.34 & 0.35 & 0.35 & 0.39 & 0.38 & 0.43 & 0.49 & 0.49 \\
\hline $\mathrm{Ca}$ & 0.84 & 0.83 & 0.79 & 0.72 & 0.90 & 0.63 & 0.72 & 0.79 & 0.78 & 0.67 \\
\hline $\mathrm{Al}$ & 4.02 & 4.02 & 4.02 & 4.03 & 4.14 & 4.03 & 4.05 & 4.04 & 4.06 & 4.02 \\
\hline Total & 15.96 & 16.00 & 15.97 & 15.98 & 16.09 & 15.98 & 16.04 & 15.95 & 16.00 & 15.93 \\
\hline
\end{tabular}


Table 2. The compositions of garnet for sample 09-2914-4.

\begin{tabular}{|c|c|c|c|c|c|c|c|c|c|c|}
\hline \multirow{2}{*}{$\begin{array}{c}\text { Composition } \\
\mathrm{Na}_{2} \mathrm{O}\end{array}$} & \multicolumn{10}{|c|}{ Center edge } \\
\hline & 0.07 & 0.02 & 0.02 & 0.07 & 0.02 & 0.00 & 0.02 & 0.02 & 0.00 & 0.00 \\
\hline $\mathrm{FeO}$ & 27.80 & 28.31 & 28.70 & 28.72 & 30.14 & 29.61 & 30.52 & 31.16 & 29.39 & 33.04 \\
\hline $\mathrm{K}_{2} \mathrm{O}$ & 0.00 & 0.00 & 0.00 & 0.00 & 0.00 & 0.01 & 0.02 & 0.00 & 0.00 & 0.02 \\
\hline $\mathrm{SiO}_{2}$ & 36.99 & 36.91 & 37.04 & 36.94 & 36.94 & 36.66 & 37.01 & 36.92 & 35.63 & 37.18 \\
\hline $\mathrm{MnO}$ & 8.02 & 7.66 & 7.65 & 7.25 & 6.92 & 6.65 & 5.35 & 3.43 & 2.22 & 0.90 \\
\hline $\mathrm{MgO}$ & 1.27 & 1.28 & 1.33 & 1.36 & 1.47 & 1.45 & 1.50 & 1.64 & 1.68 & 2.09 \\
\hline $\mathrm{CaO}$ & 3.81 & 3.98 & 3.94 & 4.06 & 4.14 & 3.99 & 3.86 & 3.91 & 5.02 & 5.28 \\
\hline $\mathrm{Al}_{2} \mathrm{O}_{3}$ & 20.81 & 21.07 & 21.24 & 21.17 & 21.17 & 20.97 & 21.19 & 20.90 & 21.24 & 21.38 \\
\hline Total & 98.78 & 99.27 & 99.95 & 99.57 & 100.82 & 99.34 & 99.47 & 97.98 & 95.21 & 99.92 \\
\hline $\mathrm{Na}$ & 0.02 & 0.01 & 0.01 & 0.02 & 0.01 & 0.00 & 0.01 & 0.01 & 0.00 & 0.00 \\
\hline $\mathrm{Fe}$ & 3.80 & 3.86 & 3.88 & 3.90 & 4.06 & 4.04 & 4.14 & 4.27 & 4.12 & 4.44 \\
\hline K & 0.00 & 0.00 & 0.00 & 0.00 & 0.00 & 0.00 & 0.00 & 0.00 & 0.00 & 0.00 \\
\hline Si & 6.05 & 6.01 & 5.99 & 5.99 & 5.95 & 5.98 & 6.00 & 6.05 & 5.97 & 5.97 \\
\hline $\mathrm{Mn}$ & 1.11 & 1.06 & 1.05 & 1.00 & 0.94 & 0.92 & 0.73 & 0.48 & 0.31 & 0.12 \\
\hline $\mathrm{Mg}$ & 0.31 & 0.31 & 0.32 & 0.33 & 0.35 & 0.35 & 0.36 & 0.40 & 0.42 & 0.50 \\
\hline $\mathrm{Ca}$ & 0.67 & 0.69 & 0.68 & 0.71 & 0.71 & 0.70 & 0.67 & 0.69 & 0.90 & 0.91 \\
\hline $\mathrm{Al}$ & 4.01 & 4.04 & 4.05 & 4.05 & 4.02 & 4.03 & 4.05 & 4.04 & 4.20 & 4.05 \\
\hline Total & 15.96 & 16.01 & 16.00 & 15.99 & 16.05 & 16.01 & 15.98 & 15.93 & 15.95 & 16.01 \\
\hline
\end{tabular}

Table 3. The compositions of matrix garnet.

\begin{tabular}{|c|c|c|c|}
\hline \multirow{2}{*}{$\begin{array}{c}\text { Composition } \\
\mathrm{Na}_{2} \mathrm{O}\end{array}$} & \multicolumn{3}{|c|}{ Center edge } \\
\hline & 0.05 & 0.03 & 0.05 \\
\hline $\mathrm{FeO}$ & 30.49 & 31.83 & 31.92 \\
\hline $\mathrm{K}_{2} \mathrm{O}$ & 0.03 & 0.02 & 0.03 \\
\hline $\mathrm{SiO}_{2}$ & 37.54 & 37.32 & 37.17 \\
\hline $\mathrm{MnO}$ & 0.77 & 0.93 & 1.16 \\
\hline $\mathrm{MgO}$ & 2.05 & 2.30 & 2.09 \\
\hline $\mathrm{CaO}$ & 7.61 & 5.43 & 5.38 \\
\hline $\mathrm{Al}_{2} \mathrm{O}_{3}$ & 21.13 & 21.35 & 21.43 \\
\hline Total & 99.71 & 99.19 & 99.28 \\
\hline $\mathrm{Na}$ & 0.02 & 0.01 & 0.02 \\
\hline $\mathrm{Fe}$ & 4.08 & 4.29 & 4.30 \\
\hline $\mathrm{K}$ & 0.01 & 0.00 & 0.01 \\
\hline $\mathrm{Si}$ & 6.01 & 6.01 & 5.99 \\
\hline $\mathrm{Mn}$ & 0.10 & 0.13 & 0.16 \\
\hline $\mathrm{Mg}$ & 0.49 & 0.55 & 0.50 \\
\hline $\mathrm{Ca}$ & 1.31 & 0.94 & 0.93 \\
\hline $\mathrm{Al}$ & 3.99 & 4.05 & 4.07 \\
\hline Total & 16.02 & 15.97 & 16.02 \\
\hline
\end{tabular}

sis was conducted in the electron probe laboratory in Guangzhou Institute of Geochemistry, Chinese Academy of Sciences, using the electron probe microscope (instrument model JEOL, JXA-8100, analysis conditions for the acceleration voltage is $15.0 \mathrm{kv}$, beam $2 \times 10^{-8} \mathrm{~A}$, beam $\left.1 \mu \mathrm{m}\right)$. PRZ is adopted for error correction method.

The garnet compositions are projected in the Coleman garnet classification diagram (Coleman, 1965). Garnet composition data are all plotted in almandine zone (Figure 3), and the average composition is that almandine is about $67 \%$ - 87\%, calcium aluminium garnet approximately 13\% - 24\%, and pyrope approximately $2 \%-12 \%$. $\mathrm{Gt}_{1}$ garnets comprise $66.83 \%$ - 76.42\% almandine, 3.63\% - 13.82\% spessartine, 10.65\% - 14.08\% essonite, and 5.27 - 8.46 pyrope. From the center to the margin, the molecular content of almandine garnet stone and pyrope 


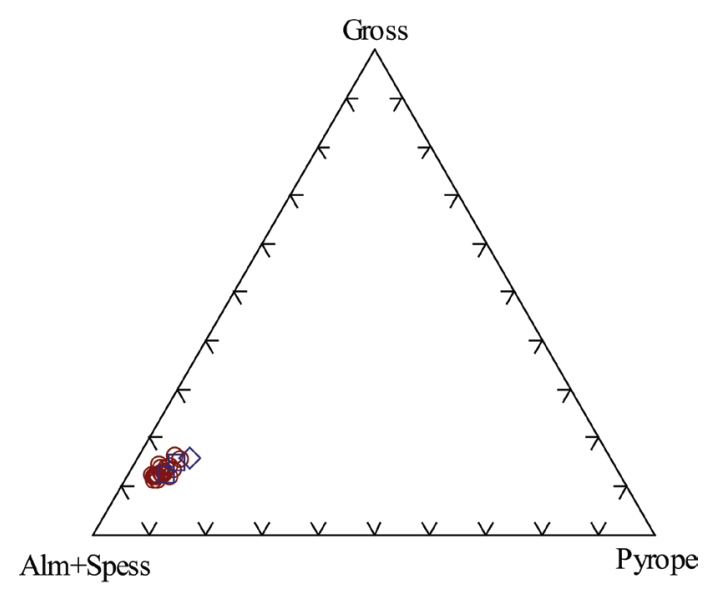

Figure 3. The triangle plot for garnet compositions.

gradually increase, and the spessartine content gradually decrease, and essonite content increase first and then decrease (Figure 5(a)). $\mathrm{Gt}_{1}$ has the typical characteristics of compositional zoning pattern developed in progressive metamorphism with elevated temperature and pressure. $\mathrm{Gt}_{2}$ garnets are composed of $65.11 \%-74.34 \%$ almandine, $2.04 \%$ - 17.83\% pyrope, $11.35 \%$ - 15.67\% essonite, and 5.23\% - 8.40\% pyrope. From the center to the margin, the almandine and essonite contents first increase and then decrease, and the spessartine content first decreases and then increases, and pyrope content increases all the way (Figure 5(b)). Compared with the $\mathrm{Gt}_{1}$ garnet, compositional zoning pattern of $\mathrm{Gt}_{2}$ garnets are more complicated, and it reflects the complex metamorphic reaction. $\mathrm{Gt}_{3}$ garnets have a higher percentage of pyrope than the $\mathrm{Gt}_{1}$ and $\mathrm{Gt}_{2}$ garnets (Figure $5(\mathrm{c})$ ). Garnet compositions of the three categories suggest that the rock intermediate grade regional metamorphism [10].

In Nadi garnet composition and metamorphic zone diagram (Figure 4), although all plotted either within or close to the kyanite zone, garnets in each category spread out or are concentrated at different areas. All Gt $\mathrm{t}_{1}$ and $\mathrm{Gt}_{3}$ garnets are plotted in the kyanite zone while some $\mathrm{Gt}_{2}$ garnets are plotted in the garnet zone. $\mathrm{Gt}_{1}$ garnets spread out in the whole kyanite zone but $\mathrm{Gt}_{3}$ garnets are plotted on the part of zone that is close to the sillimanite zone. These differences suggest that $\mathrm{Gt}_{1}$ garnets grew slightly earlier than $\mathrm{Gt}_{3}$ garnets but later than $\mathrm{G}_{2}$ garnets. Projection results showed that all garnets grew in epidote-amphibolite facies to amphibolite facies metamorphism.

Electron microprobe analysis of the garnet shows the zoning within garnets is growth zoning which can truly reflect the growth environment. The average composition of garnet is $67 \%-87 \%$ almandine, $13 \%-24 \%$ essonite, and 2\% - 12\% pyrope. In Coleman garnet classification diagram, all garnets fall into the almandine zone.

Probe data show that garnets studied here have distinct compositional zoning. Garnet composition zones are generally formed by growth causes or diffusion causes. Growth zoning is caused by various factors such as material supply in the process of garnet growth at different stages. Diffusion zoning is a result of intergranular diffusion in the crystal growth process or of ion exchange reaction or pure conversion reaction after garnet stopped growing [11]. Growth zoning is characterized by increased Mg percentage and decreased Mn percentage with temperature increase [12], and especially by bell-shaped Mn profile. The garnet probe data of our samples show typical characteristics of the growth zoning, and zones in the garnets are growth zones. These garnets can be used to estimate the temperature of its environment.

Studies of the garnet composition zoning in the literature show that $\mathrm{MgO}, \mathrm{FeO}, \mathrm{MnO}$, and $\mathrm{CaO}$ contents vary with metamorphic p-t conditions. As metamorphic temperature rises, $\mathrm{MgO}$ content increases and $\mathrm{MnO}$ content decreases. $\mathrm{CaO}$ content increases gently with pressure [13]. With deepened metamorphic strength, percentages of $\mathrm{Fe}^{2+}$, and $\mathrm{Mg}^{2+}$ in garnet increase, but $\mathrm{Mn}^{2+}$ decreases. This is because $\mathrm{Mn}^{2+}$ in spessartine crystal lattice is not stable and is replaced by $\mathrm{Fe}^{2+}$ to become almandine; coordination number of a class cation $\mathrm{Ca}^{2+}$, and $\mathrm{Mn}^{2+}$, and $\mathrm{Fe}^{2+}$, and $\mathrm{Mg}^{2+}$ in pomegranate stone is $8, \mathrm{Ca}^{2+} \mathrm{Ca}^{2+}$ have the largest radius, $\mathrm{Ca}^{2+}$ present eight time coordination and need not pressure, booster will makes the coordination number increase. So, with the deterioration the content of $\mathrm{Ca}^{2+}$ is only slightly up [14].

$\mathrm{X}_{\mathrm{Gt}, \mathrm{Mg}}, \mathrm{X}_{\mathrm{Gt}, \mathrm{Fe}}, \mathrm{X}_{\mathrm{Gt}, \mathrm{Mn}}$, and $\mathrm{X}_{\mathrm{Gt}, \mathrm{Ca}}$ values of garnet in metamorphic rocks are under the influence of the chemical 


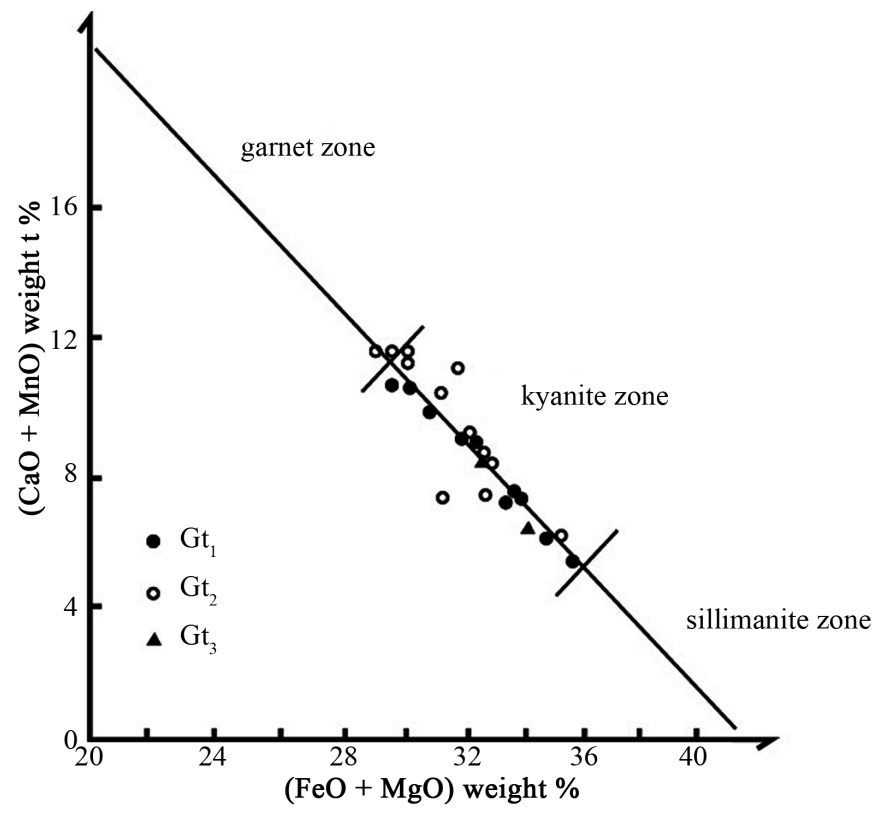

Figure 4. Diagram showing the relationship between compositional of garnets and metamorphic belt.

composition of the host rock, and under the control of metamorphic temperature, under conditions of chemical composition, their change reflects changes in metamorphic environment [15]. For any garnets in this study, composition of the core differs from that of the rim, but this composition difference for each of the three categories of garnets has their own characteristics.

For $\mathrm{Gt}_{1}$ garnets (09-2914-1) the difference is distinctive. From the center to the margin, $\mathrm{X}_{\mathrm{Mg}}$ and $\mathrm{X}_{\mathrm{Fe}}$ increase monotonically and $\mathrm{X}_{\mathrm{Mn}}$ decreases monotonically. $\mathrm{X}_{\mathrm{Ca}}$ decreases near the core and increases in the middle and then gradually decreases toward the margin (Figure 5(a)).

For $\mathrm{Gt}_{2}$ garnets (09-2914-4), the difference is minor. From the center to the margin, $\mathrm{X}_{\mathrm{Mg}}, \mathrm{X}_{\mathrm{Fe}}, \mathrm{X}_{\mathrm{Mn}}$, and $\mathrm{X}_{\mathrm{Ca}}$ show different patterns (Figure 5(b)). $X_{\mathrm{Mg}}$ increases monotonically. $X_{\mathrm{Fe}}$ increases first and then falls. $X_{\mathrm{Mn}}$ decreases first and then increases. $\mathrm{X}_{\mathrm{Ca}}$ increases gently first and then decreases. For $\mathrm{Gt}_{3}$ garnets, the difference is minor. $\mathrm{X}_{\mathrm{Mg}}$ continues to increase, $\mathrm{X}_{\mathrm{Fe}}$ waves rising and falling, $\mathrm{X}_{\mathrm{Mn}}$ to decline slowly and then rapidly decline; $\mathrm{X}_{\mathrm{Ca}}$ is wave-like rising (Figure 5(c)).

The patterns of the profile plots of $\mathrm{X}_{\mathrm{Gt}, \mathrm{Mg}}, \mathrm{X}_{\mathrm{Gt}, \mathrm{Fe}}, \mathrm{X}_{\mathrm{Gt}, \mathrm{Mn}}, \mathrm{X}_{\mathrm{Gt}, \mathrm{Ca}}$ of the above three types of garnet suggest an overall progressive metamorphism with complex metamorphic history. Garnet core grew gradually in an environment with increasing temperature and pressure. The plot pattern for the outer edge indicates that the pressure increased rapidly first with elevated temperature and then the temperature decreased dramatically, followed first by dramatical decrease of pressure and then rapid rise of temperature and gentle increase of pressure. Combines samples collection points location it can be analysed the growth environment for pomegranate stone of the samples is: rock first in regional metamorphism, produces progressive metamorphic; after that local pressure increased and led to uplift producing temprature cooling down, as pressure continues to increase and fault zone formed, part stress was released leading pressure declined; finally garnet regrow in the thermal relaxation environmental warming slightly pressurized (part of euhedral garnet also reflects the characteristics of static recrystallization). The whole process of garnet growth correspond to the different periods of orogeny, garnet core growth has characteristics of large fold-nappe in early orogenic phaseand tectonic stacking with regional lowtemperature dynamic metamorphism. Mantle and edge growth has characteristics of strike-slip, decrease, uplifted tectonic mechanisms and processes shown by the principal orogenic compressional, with progressive metamorphism, granitization and progressive deformation. Garnet did not reflect metamorphism of power degradation of late orogenic process [16].

All in all, composition characteristics of three categories of garnets imply that the garnets grew in a progressive metamorphism and that they did not undergo retrogressive metamorphism. This research coincides with Yang Weiran, who, in his view: "the beihuaiyang tectonic belt was subjected to greenschist facies metamor- 

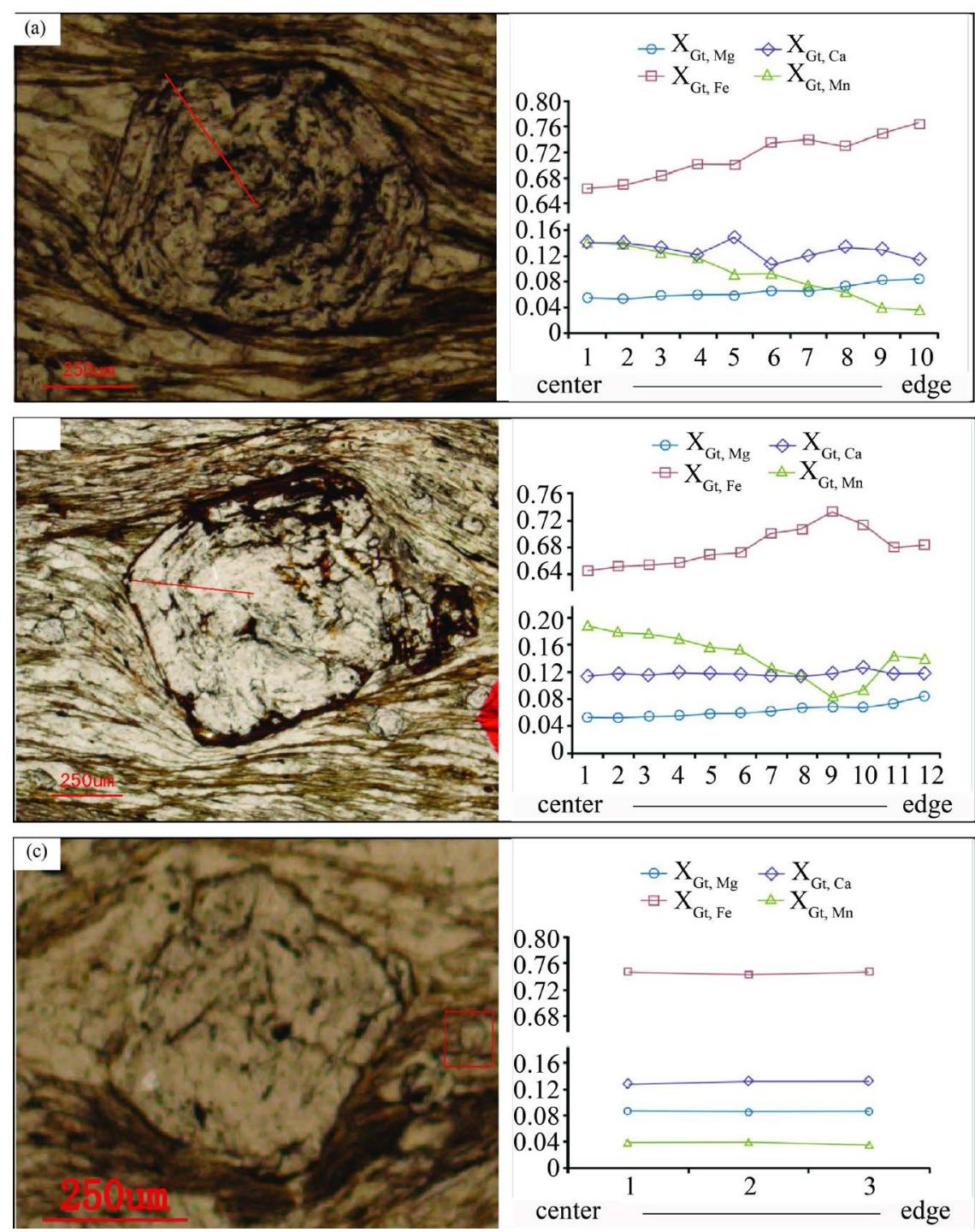

Figure 5. Compositional profile of garnet. (a) Microprobe analysis profile of $\mathrm{Gt}_{1}$ garnet (09-2914-1); (b) Microprobe analysis profile of $\mathrm{Gt}_{2}$ garnet (09-2914-4); (c) Microprobe analysis profile of $\mathrm{Gt}_{3}$ garnet (the mineral matrix). Thereinto, $\mathrm{X}_{\mathrm{Gt}, \mathrm{Fe}}=\mathrm{Fe} /\left(\mathrm{Mg}+\mathrm{Fe}^{2+}+\right.$ $\mathrm{Mn}+\mathrm{Ca}) ; \mathrm{X}_{\mathrm{Gt}}, \mathrm{Mn}=\mathrm{Mn} /\left(\mathrm{Mg}+\mathrm{Fe}^{2+}+\mathrm{Mn}+\mathrm{Ca}\right) ; \mathrm{X}_{\mathrm{Gt}, \mathrm{Mg}}=\mathrm{Mg} /\left(\mathrm{Mg}+\mathrm{Fe}^{2+}+\mathrm{Mn}+\mathrm{Ca}\right) ;$ $\mathrm{X}_{\mathrm{Gt}, \mathrm{Ca}}=\mathrm{Ca} /\left(\mathrm{Mg}+\mathrm{Fe}^{2+}+\mathrm{Mn}+\mathrm{Ca}\right)$.

phism, and metamorphic is deep along the fault zone, in the local area of garnet mica schist there are highpressure eclogite facies metamorphism". As the main rock unit in of the tectonic zone and the protolith of the surrounding country rock of the eclogites, garnet mica schist, experienced the same tectonic phases as the eclogites. These tectonic phases contributed to and left footprints in the composition zoning of the garnets in this study.

\section{Ultrastructure Deformation Characteristics of Garnet}

In order to study the phenomenon of the micro rheology of garnet and rheological mechanisms, the author carried on detailed Transmission Electron Microscope (TEM) analysis of the garnet samples in the physical and chemical center in China University of Science and Technology. Analysis shows that there is a link between the characteristics of dislocations with the garnets and tectonic history of the fault zone. Free dislocations, dislocation walls, small amounts of dislocation arcs, and circular spots formed by water molecules were observed. 
Free dislocations are mostly long and straight mainly in two directions, along one of which dislocations dominate (Figure 6(a)). This is the direction in which it is easy for garnet dislocation slip to take place. In complex crystals, surface most prone to sliding is generally parallel to the weakest chemical bonds between the lattice planes. For garnet, the sliding surface is $1 / 2<111>\{110\}$ and the other slip systems is $<100>$ the $\{001\}$, because $1 / 2<111><100>$ is two short sets of crystal lattice dislocations Borges vector, keys in the other direction is weak and liable to undermine formation of slip surface. Dislocation bowing turns a small amount, and radian is smaller. Dislocation wall is clear and tidy, it is obvious that both sets of slip surface on the flat sliding surface parallel to the dislocation in the met and formed equally spaced, and are the result of dislocation slip intersect (Figures 6(b)-(d)). But with cold-finished condition observed diffuse tangles of dislocations wall is significantly different in Asia and grained low dislocation density, intracellular corrugated matting, lattice of notes bent, dislocation climb should be moved under the control of slip was Weertman creep [17]. Mechanism is the relatively high temperature, low stress and strain, roughly comparable to the middle and lower crust temperature and pressure environment. Because the two groups of varying degrees of slip surface slip, so crystal cell morphology is not isometric, but a bit long ellipsoidal, consistent with $\mathrm{Gt}_{3}$ and Sub grain recrystallization grain morphology under microscopy.

For garnet, dislocation slip and climb can only occur as the leading mechanisms of plastic deformation when $\mathrm{T}$ is $>0.8 \mathrm{Tm}$ (about $900^{\circ} \mathrm{C}$ ) [18]. From the picture in Figure 6, you can see the contrast of small circular spots (Figure 6(b), Figure 6(c), Figure 6(e) and Figure 6(f)), and this should be water molecules in garnet repeatedly reported in recent years, dislocation line around water molecules is little or no. Because of water molecular diffusion under high temperatures accelerate, priority mission of occupying space and room in the lattice forming small water molecules, water molecules gathered again through diffusion and form larger molecules of water. Therefore, water molecules are the result of static recovery at high temperature [19]. These two different structural features illustrate garnet had undergone a certain high temperature static recrystallization of the restore process after experiencing a strong dislocation slip deformation [20].

Dynamic recrystallization is the result of reduced dislocation density in the deformed crystal. Recrystalliza-
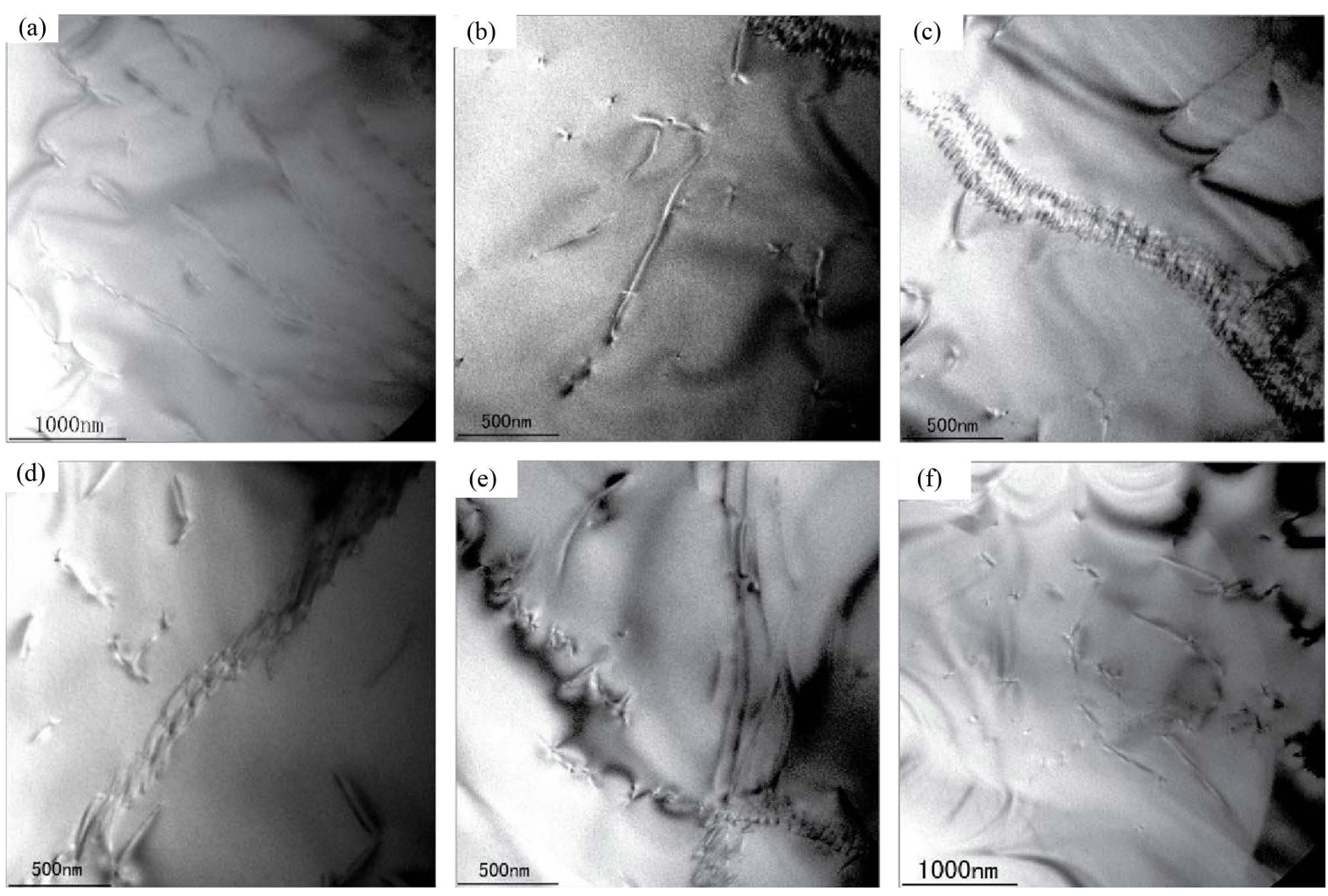

Figure 6. TEM photos of garnet $\left(\mathrm{Gt}_{3}\right)$. (a) Straight free dislocation; (b) Free dislocation and dislocation bow; (c) (d) Dislocation wall; (e) Dislocation bow and dislocation wall; (f) Free dislocation and the water molecules. 
tion contain nucleation and growth process of new crystal, in this process, High dislocation density of the particulate material is transferred to the boundary of the low dislocation density in the crystal lattice, the particles of weak deformation increases while the particles of strong deformation decreases. Its formation mechanism is when crystals are subjected to external stresses, due to uneven internal structure, the stress concentration generated in the secondary phase particles at the grain boundaries and, in the crystal of the type stored plastic strain energy will cause free energy difference and produces a driving force, under the action of this force, the rotation of the two mechanisms of strain in the grain boundaries and grain protuberances Guinea grains recrystallized grains formed the core, and on the basis of this it grows to a new crystal and replace the old strain grain [21]. Intensity of crystallization (ratio of the new nucleus and residual strain of grain), is closely related to size and strain. Whereas the recrystallized grain size depends primarily on differences in deformation stress, so it's often used to calculate the differences in stress.

Dynamic recrystallization falls into three types: bulging recrystallization, subgrain rotation recrystallization and grain boundary migration recrystallization. Some of the samples show small garnets at the margin of and connected with the large garnet crystals, and these are the core-mantle structures at the early stage (Figure 2(b), Figure 2(d), Figure 2(f) and Figure 2(e)). They are the product of a bulging dynamic recrystallization.

In summary, the plastic deformation of garnet in the sample is formed by plastic deformation dominated with dislocation slip mechanism along with bulging dynamic recrystallization formed by protuberantia of strainied grain boundary. According to various microstructural features of garnet, it's convinced the plastic deformation of the sample is formed in medium and slightly higher temperature conditions.

\section{The Rheological Parameters of Garnet and Rheological Parameters of Rock}

By means of probe analysis on Garnet and Muscovite in rock and Garnet-Muscovite thermometer and phengite geobarometer the formation environment can be estimated. These garnets, developed compositional zoning in progressive metamorphism, and that their rims are in equilibrium with muscovite at a temperature of $562^{\circ} \mathrm{C}$ $617^{\circ} \mathrm{C}$ [22]. Muscovite probe analysis datum are calculated based on 11 oxygen, Si atomic number ranges between 3.08 - 3.15, slightly larger than 3.0, but haven't reached ingredients of phengite [23]. Pressure is 0.77 $1.02 \mathrm{GPa}$ [22]. Conditions of temperature and pressure garnet suffered are consistent and with dislocation configuration under TEM observation and the metamorphism and deformation environment shown by the recrystallization form.

Particle size of Muscovite in garnet mica schist is small, $0.05-0.1 \mathrm{~mm}$, schistose, in the matrix it is in interphase arrangement with biotite and distribution parallel to the schistosity. Porphyroblast garnet have obvious metamorphism zone, so its edge ingredients and garnet rim of muscovite composition was chosen to estimate peak metamorphic conditions. Muscovite microprobe analysis data are shown in Table 4, calculated by 11 oxygen crystal chemical formula, the change is $3.08-3.15 \mathrm{Si}$, Si cation is slightly larger than the number of muscovite in 3.0, but has not reached phengite ingredients. According to Garnet-Muscovite geological thermometer its equilibrium temperature is estimated as $562^{\circ} \mathrm{C}-617^{\circ} \mathrm{C}$, pressure is estimated as $0.77-1.02 \mathrm{GPa}$.

Dislocation density in most metals and minerals and the stress applied have the following relationship:

$$
\sigma / 2 \mu=\alpha\left(\rho b^{2}\right)^{1 / k}
$$

$\sigma$ is the variance stress, $\mu$ is the shear modulus, $\alpha$ is material coefficient, $\rho$ is the dislocation density, $b$ is the Burgers vector, $k$ is a constant.

Material factor is currently used in the calculation of differential stress of garnet and olivine. As material factor $\alpha$ varies with different minerals, therefore, Chen corrected garnet material coefficients compared with the calculated values of other minerals, and thought the outcome of calculating the difference in stress is more reasonable when $\alpha=2.5$ [24].

12 TEM photos of samples are selected and free dislocation densities are measured an average of $\rho=6.14 \times$ $10^{8} / \mathrm{cm}^{2}$, by substituting $\rho$ on the type differential stress of $0.511 \mathrm{GPa}$. Using Parrish wet quartz flow rate formula to calculate the strain rate.

$$
\varepsilon\left(s^{-1}\right)=4.4 \times 10^{-2} \times(\sigma(\mathrm{MPa}))^{2.6} \times \exp (-27778 / T(\mathrm{~K}))
$$

Choose Garnet-Muscovite thermometer to calculate the average deformation temperature $T=89.5^{\circ} \mathrm{C}$, the 
Table 4. The representative compositions for muscovite.

\begin{tabular}{|c|c|c|c|c|c|c|c|c|}
\hline $\mathrm{Si}$ & 3.15 & 3.13 & 3.08 & 3.15 & 3.08 & 3.10 & 3.12 & 3.11 \\
\hline $\mathrm{Al}^{\mathrm{IV}}$ & 2.71 & 2.72 & 2.68 & 2.74 & 2.71 & 2.67 & 2.73 & 2.74 \\
\hline Sum_T & 5.86 & 5.85 & 5.77 & 5.88 & 5.79 & 5.76 & 5.86 & 5.85 \\
\hline $\mathrm{Ti}$ & 0.02 & 0.02 & 0.02 & 0.02 & 0.02 & 0.02 & 0.02 & 0.02 \\
\hline $\mathrm{Fe}^{2}$ & 0.10 & 0.10 & 0.27 & 0.09 & 0.23 & 0.24 & 0.11 & 0.12 \\
\hline $\mathrm{Mn}$ & 0.00 & 0.00 & 0.00 & 0.00 & 0.00 & 0.00 & 0.00 & 0.00 \\
\hline Mg & 0.07 & 0.07 & 0.06 & 0.06 & 0.07 & 0.08 & 0.06 & 0.06 \\
\hline $\mathrm{Ca}$ & 0.00 & 0.00 & 0.01 & 0.00 & 0.01 & 0.00 & 0.01 & 0.00 \\
\hline $\mathrm{Na}$ & 0.08 & 0.08 & 0.09 & 0.08 & 0.09 & 0.09 & 0.09 & 0.10 \\
\hline K & 0.78 & 0.79 & 0.78 & 0.74 & 0.77 & 0.82 & 0.77 & 0.82 \\
\hline $\mathrm{O}$ & 11.00 & 11.00 & 11.00 & 11.00 & 11.00 & 11.00 & 11.00 & 11.00 \\
\hline Fe_FeMg & 0.60 & 0.57 & 0.81 & 0.61 & 0.78 & 0.76 & 0.64 & 0.66 \\
\hline Mg_FeMg & 0.40 & 0.43 & 0.19 & 0.39 & 0.22 & 0.24 & 0.36 & 0.34 \\
\hline
\end{tabular}

calculated strain rate $4.97536 \times 10^{-10} \mathrm{~m} \cdot \mathrm{s}^{-1}$. Although moving dislocation and TEM observation of dislocation density has some differences, but the scope should also be an order of magnitude range so the results has some availability.

To further understand deformation state and deformation strength in the tectonic zone, Under the microscope, using the method of the length of the shaft [25], respectively, the XY plane, XZ and YZ plane surface, garnet and quartz of the rocks were conducted strain measurement, triaxial strain rate of garnet in garnet-mica schist in the eastern extension of Shangdan fault was calculated averaged X:Y:Z = 1.43:1.21:1, Flinn Coefficient of pomegranate stone $\mathrm{k}$ is 0.948 (Figure 7), showing garnet contingency mechanism should be a plane strain; Triaxial strain ratio of quartz is of average $\mathrm{X}: \mathrm{Y}: \mathrm{Z}=77: 6.19: 1$, and $\mathrm{k}$ value of quartz is 4.84 (Figure 8), shaft for single cigars-variant. Three axis strain ratio and Flinn coefficient of different mineral in one rock is obviously different, reflecting out this two species mineral of different strength, and on same deformation conditions strain acts are obviously different. In strong deformation domain in ductile shear belt, pomegranate stone and quartz together suffered tectonic deformation, due to their different hardness the strain they bear is not the same, quartz took most of the dependent variable, and garnet bear little strain, or as a rigid body it is only weak deformed or undeformed even under the strain. Their corresponding relations between deformation remains to be further researched.

\section{Conclusions}

Study of the structures of garnets within the Shangdan suture zone using the microscope, the TEM, and the electron microprobe enables us to reveal the characteristics and origin of these garnets and to use them to constrain the tectonic evolution of the Shandan suture zone which developed during the collision between North China plate and South China plate.

1) Garnets in all of the three categories underwent dynamic recrystallization. $\mathrm{Gt}_{1}$ and $\mathrm{Gt}_{2}$ garnets are equigranular, and ductile deformation occurs at the edge and is not as strong as $\mathrm{G}_{3}$ garnets. $\mathrm{Gt}_{3}$ garnets are small rounded elongated crystals. Dynamic recrystallized garnets of this category can be separated from the residual amorphous, and core-mantle structure is at the beginning.

2) Two main dislocations in garnet are free dislocations and dislocation wall, with small amounts of dislocation arc. Garnet dislocation motion is dominated by slip; slip surface is $1 / 2<111>\{110\}$ and $<100>\{001\}$. Garnet experienced static recrystallization process after strong dislocation glide deformation, which shows that in early-to-mid term, the rock experienced a relatively strong stress and garnet formed high density of dislocations and subgrain. Finally in the thermal relaxed stage of relatively low stress bulge type recrystallization generated, bringing about plastic deformation and dynamic recrystallization of the garnet. And water molecules in garnets suggest that the garnets have experienced a certain high-temperature static recrystallization recovery process after 


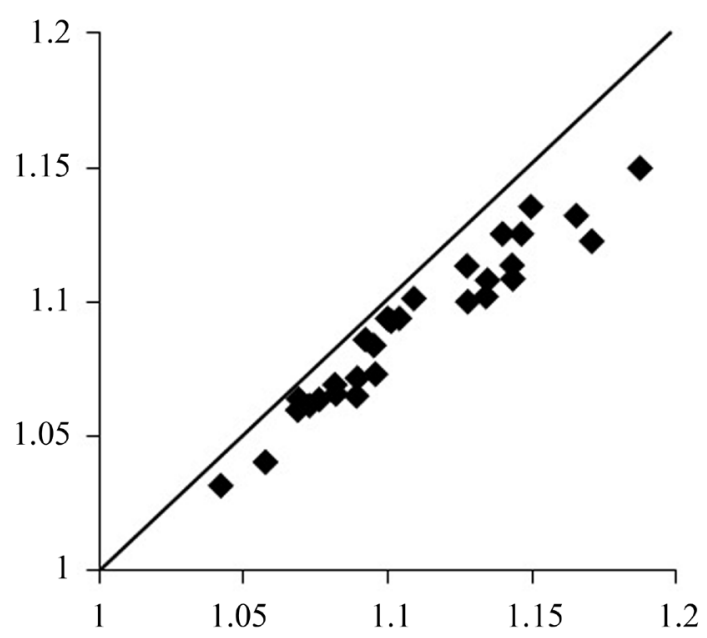

Figure 7. Flinn diagram of garnet finite strain.

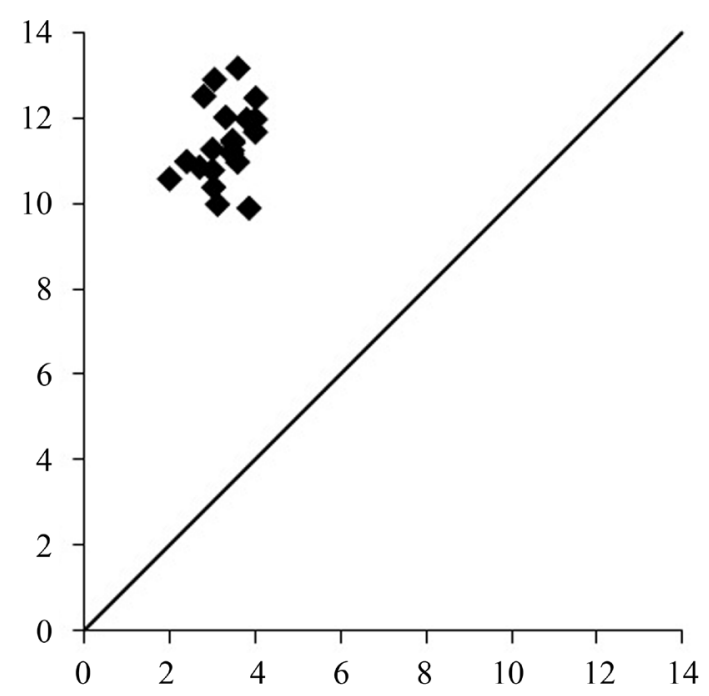

Figure 8. Flinn coefficient of quartz finite strain.

dislocation glide deformation.

3) Ompositional characteristics of garnets indicate the garnet mica schist has experienced progressive metamorphism. On Coleman garnet classification maps, garnets all fall onto the almandine zone, reflecting that the rock has gone through the intermediate regional metamorphism; on Nadi composition and metamorphic belt diagram, garnet rests primarily with kyanite zone with slightly garnet, showing that rock suffered the epidote amphibolite facies and amphibolite facies metamorphism.

4) According to geological thermometer of garnet-phengite, the temperature at which garnet mica schist developed is estimated to be $562^{\circ} \mathrm{C}-617^{\circ} \mathrm{C}$. The pressure calculated by phengite geobarmeter is $0.77-1.02 \mathrm{GPa}$. The average value of free dislocation density $(\rho)$ is $6.14 \times 10^{8} / \mathrm{cm}^{2}$. The differential stress is $0.511 \mathrm{GPa}$. Using Parrish wet quartz flow rate formula, the strain rate is calculated to be $4.97536 \times 10^{-10} \mathrm{~m} \cdot \mathrm{s}^{-1}$. The mean value of three-axis strain ratio of garnet $\mathrm{X}: \mathrm{Y}: \mathrm{Z}=1.43: 1.21: 1$, and the Flinn index of 0.948 implies plane-strain deformation of garnets. The triaxial strain ration of quartz $X: Y: Z=77: 6.19: 1$. Flinn coefficient of quartz is 4.84.

Based on mineralogical study of garnet in garnet mica schist, the metamorphism and deformation environment of Shangdan suture zone in the Tongbai area is: in the early stage of collision of the Yangtze and north China plate, the suture zone went through intermediate grade regional metamorphism; with the collision continued, the left-lateral shearing happened and caused the formation of high-density dislocations and subgrains of the garnets, then the dynamic recrystallization was formed in the process of thermal relaxation and caused the 
plastic deformation of garnets at last. So, deformation characteristics of microstructure and ultrastructure, and the composition zoning revealed formation, development and evolution of Shangdan suture zone in Tongbai area.

\section{Acknowledgements}

Financial support for this study was jointly provided by the National Natural Science Foundation of China (Grants: 41272213, 41072161).

\section{References}

[1] Zhang, G.W. and Liu, X.M. (1998) Some Remarks on China Central Orogenic System. Earth Science, 23, 443-448. (In Chinese with English Abstract)

[2] Song, C.Z., Zhang, G.W., Ren, S.L., Li, J.H. and Huang, W.C. (2009) The Research on Deformation Features of Some Structural Zones in the Qinling-Dabieshan Orogenic Belt. Journal of Northwest University (Natural Science Edition) 39, 368-380. (In Chinese with English Abstract)

[3] Liu, X.C., Lou, Y.X. and Dong, S.W. (2005) P-T-t Path of Low-Temperature Eclogites from the Tongbaishan Area. Acta Petrologica Sinica, 021, 1081-1093. (In Chinese with English Abstract)

[4] Huang, S.Y. and Xu, B. (2006) Geometry, Kinematics and Evolution of the Tongbai Orogenic Belt. Earth Science Frontiers (D Series), 36, 242-251. (In Chinese with English Abstract)

[5] Wei, C.J., Wu, Y.X., Ni, Y.Y., Chen, B. and Wang, S.G. (1999) The Characteristics of Eclogite and Its Geological Significance in Tongbai Area in Henan Province. Chinese Science, 44, 1882-1885. (In Chinese with English Abstract)

[6] Bell, T.H. and Johnson, S.E. (1995) Porphyroblast Inclusion Trails: The Key to Orogenesis. Journal of Metamorphic Geology, 7, 279-310. http://dx.doi.org/10.1111/j.1525-1314.1989.tb00598.x

[7] Bell, T.H. and Forde, A. (1995) On the Significance of Foliation Patterns Preserved around Folds by Mineral Overgrowth. Tectonohysics, 246, 171-181. http://dx.doi.org/10.1016/0040-1951(94)00263-9

[8] Williams, M.L. (1994) Sigmoidal Inclusion Trails, Punctuated Fabric Development, and Interactions between Metamorphism and Deformation. Journal of Metamorphic Geology, 12, 1-21. http://dx.doi.org/10.1111/j.1525-1314.1994.tb00001.x

[9] He, T.X. (1980) Metamorphic Petrology. Geological Publishing House, Beijing, 60-65. (In Chinese with English Abstract)

[10] Clarke, G.L., Aitchison, J.C. and Cluzel, D. (1997) Eclogites and Blueschists of Pam Penisula, NE New Caledonia: Are Appraisal. Journal of Petrology, 38, 843-876. http://dx.doi.org/10.1093/petroj/38.7.843

[11] Spear, F.S. and Daniel, C.G. (2001) Diffusion Control of Garnet Growth, Harpswell Neck, Maine, USA. Journal of Metamorphic Geology, 19, 179-195. http://dx.doi.org/10.1046/j.0263-4929.2000.00306.x

[12] Cygan, R.T. and Lasaga, A.G. (1985) Self-Diffusion of Magnesium in Garnet at 750 to $900^{\circ}$ C. Science, 285, 328-350.

[13] Menzer, G. (1928) Die kristallstrktur der Granate. Zeitschrift für Kristallographie, 69, 300-396.

[14] O’neill, B., Bass, J.D., Smyth, J.R. and Vaughan, M.T. (1989) Elasticity of Grossular-Pyrope-Almandine Garnet. Journal of Geophysical Research, 94, 17819-17824. http://dx.doi.org/10.1029/JB094iB12p17819

[15] Chen, N.S. and Sun, M. (2003) Major- and Trace-Element Zoning in Metamorphic Garnets and Their Metamorphic Process Implications. Earth Science Frontiers, 10, 315-320. (In Chinese with English Abstract)

[16] Ji, S.C. and Martignole, J. (1997) Fracturing of Garnet Crystals in Anisotropic Metamorphic Rocks during Uplift. Journal of Structure Geology, 19, 603-620. http://dx.doi.org/10.1016/S0191-8141(97)00006-0

[17] Nicolas, A. and Poirier, J.P. (1976) Crystalline Plasticity and Solid State Flow in Metamorphic Rocks. John Wiley \& Sons, New York.

[18] Voegele, V., Ando, J.I. and Cordier, P. (1998) Plastic Deformation of Silicate Garnets I High-Pressure Experiments. Physics of the Earth and Planetary Interiors, 108, 305-318. http://dx.doi.org/10.1016/S0031-9201(98)00110-1

[19] Wang, Y.F. and Jin, Z.M. (2001) Diffusion Creep of Rocks and Its Implications. Geological Science and Technology Information, 20, 5-10. (In Chinese with English Abstract)

[20] Brok, B.D. and Kruhl, J.H. (1996) Ductility of Garnet as an Indicator of Extremely High Temperature Deformation: Discussion. Journal of Structural Geology, 18, 1369-1373. http://dx.doi.org/10.1016/S0191-8141(96)00064-8

[21] Prior, D.J., Wheeler, J. and Brndnker, F.E. (2000) Crystal Plasticity of Natural Garnet: New Microstructures Evidence. Geology, 28, 1003-1006. http://dx.doi.org/10.1130/0091-7613(2000)28<1003:CPONGN>2.0.CO;2

[22] Ren, S.L., Song, C.Z., Lin, S.F., Zhang, H.R., Li, J.H., Tu, W.C., Zhang, H. and Zhang, J.J. (2011) Mineralogy Feature 
and Tectonic Significance of Garnet from Garnet-Mica Schist at the West Section of Xinyang-Shucheng Fault Belt. Chinese Journal of Geology, 46, 350-363. (In Chinese with English Abstract)

[23] Massonne, H.J. and Szpurka, Z. (1997) Thermodynamic Properties of White Micas on the Basis of High-Pressure Experiments in the Systems $\mathrm{K}_{2} \mathrm{O}-\mathrm{MgO}-\mathrm{Al}_{2} \mathrm{O}_{3}-\mathrm{H}_{2} \mathrm{O}$ and $\mathrm{K}_{2} \mathrm{O}-\mathrm{FeO}-\mathrm{Al}_{2} \mathrm{O}_{3}-\mathrm{SiO}_{2}-\mathrm{H}_{2} \mathrm{O}$. Lithos, 41, 229-250. http://dx.doi.org/10.1016/S0024-4937(97)82014-2

[24] Chen, Y., Wei, C.J., Zhang, J.S. and Chu, H. (2005) Phase Equilibria of Mica-Schists and Gneisses in the HP-UHP Belt of Southern Dabie Shan. Acta Petrologica Sinica, 21, 1657-1668. (In Chinese with English Abstract)

[25] Zheng, Y.D. and Chang, Z.Z. (1985) Finite Strain Measurement and Ductile Shear Zones. Geological Publishing House, Beijing, 188. (In Chinese with English Abstract) 
Scientific Research Publishing (SCIRP) is one of the largest Open Access journal publishers. It is currently publishing more than 200 open access, online, peer-reviewed journals covering a wide range of academic disciplines. SCIRP serves the worldwide academic communities and contributes to the progress and application of science with its publication.

Other selected journals from SCIRP are listed as below. Submit your manuscript to us via either submit@scirp.org or Online Submission Portal.
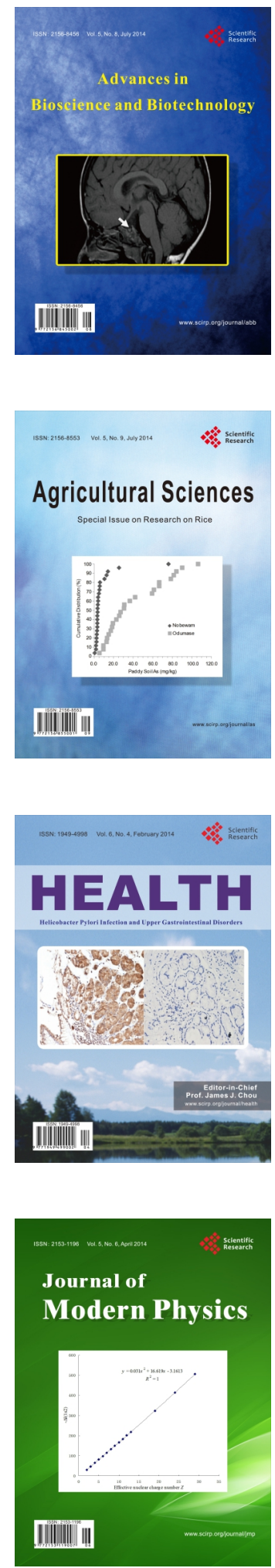
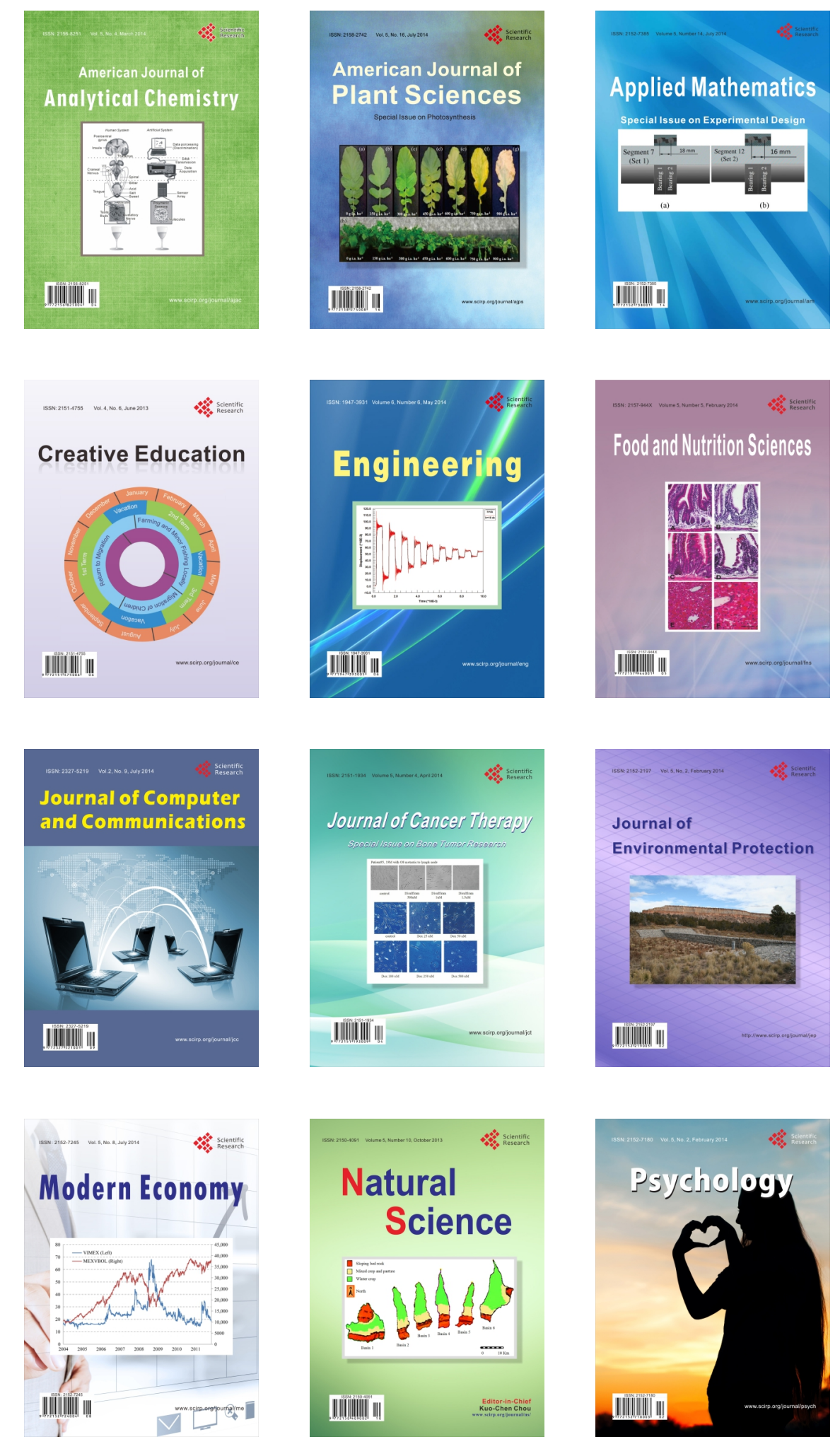